\title{
Radon and thoron exhalation rate, emanation factor and radioactivity risks of building materials of the Iberian Peninsula
}

\author{
Samuel Frutos-Puerto ${ }^{\text {Corresp., } 1}$, Eduardo Pinilla-Gil ${ }^{1}$, Eva Andrade ${ }^{2,3}$, Mário Reis ${ }^{2,3}$, Maria José Madruga ${ }^{2,3}$, Conrado \\ Miró Rodríguez ${ }^{3,4}$ \\ 1 Department of Analytical Chemistry, University of Extremadura, Badajoz, Spain \\ 2 Laboratorio de Proteçao e Segurança Radiológica, Universidade de Lisboa, Lisboa, Portugal \\ 3 Centro de Ciencias e Tecnologias Nucleares, Bobadela, Portugal \\ 4 Department of Applied Physics, University of Extremadura, Cáceres, Spain \\ Corresponding Author: Samuel Frutos-Puerto \\ Email address: samfrutosp@unex.es
}

Radon $\left({ }^{222} \mathrm{Rn}\right)$ and thoron $\left({ }^{220} \mathrm{Rn}\right)$ are radioactive gases emanating from geological materials. Inhalation of these gases is closely related to an increase in the probability of lung cancer if the levels are high. The majority of studies focus on radon, and the thoron is normally ignored by its short half-life (55.6 s). However, also the thoron decay products can cause a significant increase in dose. In buildings with high radon levels, the main mechanism for entry of radon is pressure-driven flow of soil gas through cracks in the floor. Both radon and thoron can also be released from building materials to the indoor atmosphere. In this work, we study the radon and thoron exhalation and emanation properties of an extended variety of common building materials manufactured in the Iberian Peninsula (Portugal and Spain) but exported and used in all countries of the world. Radon and thoron emission from samples collected in the closed chamber was measured by an active method that uses a continuous radon/thoron monitor. The correlations between exhalation rates of these gases and their parent nuclide exhalation (radium/thorium) concentrations were examined. Finally, indoor radon and thoron and the annual effective dose were calculated from radon/thoron concentrations in the closed chamber. Zircon is the material with the highest concentration values of ${ }^{226} \mathrm{Ra}$ and ${ }^{232} \mathrm{Th}$ and the exhalation and emanation rates. Also in the case of zircon and some granites, the annual effective dose was higher than the annual exposure limit for the general public of 1 $\mathrm{mSv} \mathrm{y}^{-1}$, recommended by the European regulations. 
1 Radon and thoron exhalation rate, emanation factor

2 and radioactivity risks of building materials of the 3 Iberian Peninsula

4 S. Frutos-Puerto ${ }^{1}$, E. Pinilla-Gil ${ }^{1}$, E. Andrade ${ }^{2,3}$, M. Reis ${ }^{2,3}$, M.J. Madrugaa ${ }^{2,3}$, C. Miró ${ }^{4}$

5

$6{ }^{1}$ Department of Analytical Chemistry, University of Extremadura, Av. de Elvas, s/n, 06006

7 Badajoz, Spain

$8 \quad{ }^{2}$ Centro de Ciências e Tecnologias Nucleares, Estrada Nacional 10, ao km 139,7, 2695-066

9 Bobadela LRS, Portugal

$10{ }^{3}$ Laboratório de Proteção e Segurança Radiológica, Instituto Superior Técnico, Universidade de

11 Lisboa, Estrada Nacional 10, ao km 139,7, 2695-066 Bobadela LRS, Portugal

$12{ }^{4}$ Department of Applied Physics, University of Extremadura, Av. de la Universidad, s/n, 10005

13 Cáceres, Spain

15 Corresponding Author:

16 S. Frutos-Puerto ${ }^{1}$

17 Av. de Elvas, s/n, 06006 Badajoz, Spain

18 samfrutosp@unex.es 


\section{Abstract}

Radon $\left({ }^{222} \mathrm{Rn}\right)$ and thoron $\left({ }^{220} \mathrm{Rn}\right)$ are radioactive gases emanating from geological materials. Inhalation of these gases is closely related to an increase in the probability of lung cancer if the levels are high. The majority of studies focus on radon, and the thoron is normally ignored due to its short half-life (55.6 s). However, also the thoron decay products can cause a significant increase in dose. In buildings with high radon levels, the main mechanism for entry of radon is the pressuredriven flow of soil gas through cracks in the floor. Both radon and thoron can also be released from building materials to the indoor atmosphere.

In this study, the ${ }^{222} \mathrm{Rn}$ and ${ }^{220} \mathrm{Rn}$ exhalation rates (mass and surface) and the emanation coefficients of an extended variety of common building materials manufactured in the Iberian Peninsula (Portugal and Spain) but exported and used in all countries of the world were determined by using active measuring system. Radon and thoron emission from samples collected in the closed chamber was measured by an active method that uses a continuous radon/thoron monitor. The correlations between exhalation rates of these gases and their parent nuclide exhalation (radium/thorium) concentrations were examined. Finally, indoor radon and thoron and the annual effective dose were calculated from radon/thoron concentrations in the closed chamber. Zircon is the material with the highest concentration values of ${ }^{226} \mathrm{Ra}$ and ${ }^{232} \mathrm{Th}$ and the exhalation and emanation rates. Also in the case of zircon and some granite, the annual effective dose was higher than the annual exposure limit for the general public of $1 \mathrm{mSv} \mathrm{y}^{-1}$, recommended by the European regulations.

Keywords: Radon; thoron; building materials; exhalation rate; annual effective dose.

\section{Introduction}

Radon and thoron are significant contributors to the average dose from natural background sources of radiation. They represent approximately half of the estimated dose from exposure to all natural sources of ionizing radiation (UNSCEAR, 2008).

Inhalation of these radioactive gases and their decay products can cause health risks, especially in poor ventilate areas. Long-term exposure to high levels of radon/thoron in home and working area increases risk of developing lung cancer $[1,3]$. Radon is the second leading cause of increase of the probability of lung cancer after tobacco smoke (World Health Organization, 2009). 
After its formation, these two radioisotopes are susceptible to escape, firstly from the grains constituting the material (known as emanation), and secondly, from the surface of the material (known as exhalation). These parameters depend, among other factors, on the half-life, consequently affecting the accumulation rate of these gaseous radioisotopes in indoor environments, and therefore, to the exposure of the human body to radiation. For radon, the halflife is 3.825 days while for thoron, just $55.6 \mathrm{~s}$ so, due to this difference, the effective dose from thoron and its progeny $\left({ }^{212} \mathrm{~Pb}\right.$ and $\left.{ }^{212} \mathrm{Bi}\right)$ is estimated around of $10 \%$ of that due to radon and its progeny $\left({ }^{214} \mathrm{~Pb}\right.$ and $\left.{ }^{214} \mathrm{Bi}\right)$ in indoor environments (United Nations Scientific Committee on the Effects of Ionisin Radiation (UNSCEAR), Sources, Effects and Risks of Ionizing Radiation, Report to the General Assembly, 2016).

These factors lead to a complicated thoron measurement technique resulting in, the majority of the existing studies focus on the radon [2-12]. Many of these studies also include measures of ${ }^{40} \mathrm{~K},{ }^{226} \mathrm{Ra}$ and ${ }^{232} \mathrm{Th}$ and risk indexes definitions trying to evaluate the radiological health hazards of these radionuclides (Turhan \& Gündüz, 2008; De With, De Jong \& Röttger, 2014; Kumar et al., 2015; Kayakökü, Karatepe \& Doğru, 2016; Madruga et al., 2018) or the effective dose due to radon and its progeny (Sabiha-Javied, Tufail \& Asghar, 2010).

Nevertheless, despite thoron indoor concentration is generally lower than for the radon, the ${ }^{212} \mathrm{~Pb}$ thoron progeny (half-life of $10.6 \mathrm{~h}$ ) can accumulate to significant levels in breathable air, aggravating its inhalation risk (World Health Organization, 2009). Some studies [23-25] have demonstrated that thoron concentrations can be comparable to radon and its progeny in some areas of elevated radiological risk. Furthermore, computational studies (de With \& de Jong, 2011) taking into account factors such as the ventilation and air exchange, the building dimensions, dispersion and deposition, mitigation measures, and material properties indicates that thoron effective doses can reach the $35 \%$ of the total contribution.

Therefore, these studies demonstrate the recent and growing interest that has emerged in recent decades by the study of thoron [27-35] in building materials [16, 19, 36, 37] although no further studies has been reported yet focusing in the assessment of the thoron risk index in the building materials used in buildings.

Among the methods to measure both exhalation rate and emanation factor of radon and thoron isotopes in building materials, passive methods, that use solid-state nuclear track detector, 
accumulation chamber methods and active methods with radon/thoron monitors, can be found (Zhang et al., 2012).

In previous work, the gamma radiations emitted from ${ }^{226} \mathrm{Ra},{ }^{232} \mathrm{Th}$ and ${ }^{40} \mathrm{~K}$ for some of these materials were studied, as well as the radiological health hazards associated with the external gamma radiation (Madruga et al., 2018). In another study (Frutos-Puerto et al., 2018), a technique of measurement of thoron had been developed and applied to the analysis of exhalation of 5 materials. In the present work, expanded with more materials, we study the radon and thoron exhalation and emanation properties of an extended variety of common building materials used in the Iberian Peninsula (Portugal and Spain). The correlations between exhalation rates of these gases and their parent nuclide exhalation (radium/thorium) concentrations were examined. Furthermore, indoor radon/thoron and the annual effective dose were calculated from radon/thoron concentrations in the closed chamber. Measurements were carried out by an active method that uses a continuous radon/thoron monitor RTM1688-2 (SARAD GmbH, Dresden, Germany).

\section{Materials and methods}

\section{Materials and sample preparation}

Forty-one samples from quarries and suppliers of the most commonly used building materials manufactured in the Iberian Peninsula were collected. The mass of each sample ranged between 1 and $5 \mathrm{~kg}$. Fig. 1 shows the geographical origin of the materials. The materials were divided in two classes: materials coming from natural sources, NM, naturally occurring radioactive materials (NORM) incorporating waste after industrial processing, PM ("Directive. 2013/59/Euratom of 5 December 2013,” 2014). Within each classification of materials are found:

\section{Materials type NM:}

- Concretes. Used in bulk amounts:

- Conventional.

- $\quad 100 \%$ of the natural aggregate becomes electrical furnace slags.

- $100 \%$ of the natural aggregate becomes blast furnace slags.

- Self-compacting.

- High-resistance.

- Mortars of resistance 5 and 7.5, respectively. 
- Cements. Used in bulk amounts and superficial applications:

- Type I Portland cement with less than 3\% fly ash.

- White cement.

- Cement glue.

- Rapid cement.

- Natural stones. Used as bulk and superficial products:

- Marble.

- Granite.

- Slate.

- Ceramic tiles as refractory and ceramic products to cover floors and walls, mainly:

- Tiles

- Raw materials of very different types and composition:

- Wood collected from Eucalyptus and Castahea Sativa trees.

- $\quad$ Aggregates as sand or clay bricks.

- Zircon.

Materials type PM:

- Industrial products resulting from the sulphates industry of the North of Spain:

- Gypsum

- Plastic cement

Sample preparation consisted in to crushing and drying building materials in an oven for $48 \mathrm{~h}$ at $105^{\circ} \mathrm{C}$, prior to its grounding and sieving ( $2 \mathrm{~mm}$ particle size).

\section{Gamma spectroscopic analysis}

To carry out the $\gamma$-emissions measurements, the milled samples were dried and placed in 160 $\mathrm{cm}^{3}$ cylindrical containers made of plastic or in $1000 \mathrm{~cm}^{3}$ Marinelli beakers, both, hermetically sealed for 28 or more days. This period is sufficient for equilibrium to occur between the radioisotopes of ${ }^{226} \mathrm{Ra}$ and ${ }^{232} \mathrm{Th}$ initially contained in the material and their decay products.

To obtain the ${ }^{232} \mathrm{Th}$ and ${ }^{226} \mathrm{Ra}$ content an HPGe semiconductor detector was employed according to the methodology followed by Madruga et al. (Madruga et al., 2018). The ${ }^{232} \mathrm{Th}$ activity was determined by means of the $\gamma$-emissions of ${ }^{228} \mathrm{Ac}(911 \mathrm{keV})$ and ${ }^{208} \mathrm{Tl}(583.01 \mathrm{keV})$ 
138 and that of ${ }^{226} \mathrm{Ra}$ by means of those from ${ }^{214} \mathrm{Bi}(609.3$ and $1764.5 \mathrm{keV})$ and ${ }^{214} \mathrm{~Pb}(351.9 \mathrm{keV})$

139 assuming that both radioactive series are left in secular equilibrium.

140

141

142

143

144

145

146

147

148

149

150

151

152

153

154

155

156

157

158

159

160

161

162

163

164

165

166

A 50\% relative efficiency broad energy HPGe detector (Canberra BEGe model BE5030), with an active volume of $150 \mathrm{~cm}^{3}$ and a carbon window was used for the gamma spectrometry measurements. A lead shield with copper and tin lining shields the detector from the environmental radioactive background. Standard nuclear electronics was used and the software Genie 2000 (version 3.0) was employed for the data acquisition and spectral analysis. The detection efficiency was determined using NIST-traceable multi-gamma radioactive standards (Eckert \& Ziegler Isotope Products) with an energy range from $46.5 \mathrm{keV}$ to $1836 \mathrm{keV}$ and customized in a waterequivalent epoxy resin matrix (density of $1.15 \mathrm{~g} \mathrm{~cm}^{-3}$ ) to exactly reproduce the geometries of the samples. GESPECOR software (version 4.2) was used to correct for matrix (self-attenuation) and coincidence summing effects, as well as to calculate the efficiency transfer factors from the calibration geometry to the measurement geometry (whenever needed). The stability of the system (activity, FWHM, centroid) was checked at least once a week with a ${ }^{152} \mathrm{Eu}$ certified point source. The acquisition time was set to 15 hours and the photopeaks used for the activity determination were: $295.2 \mathrm{keV}(\mathrm{Pb}-214), 351.9 \mathrm{keV}(\mathrm{Pb}-214)$ and $609.3 \mathrm{keV}(\mathrm{Bi}-214)$ for ${ }^{226} \mathrm{Ra}$; $238.6 \mathrm{keV}(\mathrm{Pb}-$ 212), $583.2 \mathrm{keV}$ (Tl-208) and $911.2 \mathrm{keV}$ (Ac-228) for ${ }^{228} \mathrm{Ra}$ and $1460.8 \mathrm{keV}$ for K-40. Figure 2 presents as an example a gamma-ray spectrum for a granite sample. The overall quality control of the technique is guaranteed by the accreditation of the laboratory according to the ISO/IEC 17025:2005 standards and through the participation in intercomparison exercises organized by international organizations (Merešová, Wätjen \& Altzitzoglou, 2012; Xhixha et al., 2017).In summary, the activity concentration for ${ }^{232} \mathrm{Th}$ and ${ }^{226} \mathrm{Ra}(A)$ was calculated by the following expression:

$$
C=\frac{N}{t P M \epsilon_{f}}
$$

where $N$ stands for net counts, $t$ for data collection time, $P$ for emission probability, $\mathrm{M}$ for mass of the sample and $\epsilon_{f}$ for efficiency of the detector for the corresponding peak. Besides, uncertainty in the yield is also include since several $\gamma$-ray peaks were used for the calculation of ${ }^{232} \mathrm{Th}$ and ${ }^{226}$ Ra activity.

Determination of massic exhalation rate and emanation factor 
Exhalation is the amount of radon (radon activity) as obtained from a given layer (geological material on the surface/surface exposure) mainly the outer thinner part of the crust and it is given in $\mathrm{Bq} \mathrm{h}^{-1}$, according to the Netherlands Standardization Institute ("Netherlands Standardization Institute. Dutch Standard: Radioactivity measurement. Determination method of the rate of the radon exhalation of dense building materials," 2001). Exhalation can be related to the mass of the samples (massic radon/thoron exhalation, and its value is expressed $\mathrm{Bq} \mathrm{kg}^{-1} \mathrm{~h}^{-1}$ ). The method already referred $[5,39]$ and similar to that of other authors (Hassan et al., 2011) was employed to assess the massic exhalation of ${ }^{222} \mathrm{Rn}$ and ${ }^{220} \mathrm{Rn}$ and it is schematized in Fig. 3.

The calculation of ${ }^{222} \mathrm{Rn}$ and ${ }^{220} \mathrm{Rn}$ exhalation was carried out according to the expressions presented in the Miró et al. (Miro et al., 2014) from the formula of the temporal variation of the radon concentration $C(\mathrm{t})$, in $\mathrm{Bq} \mathrm{m}^{-3}$ :

$$
\frac{d c}{d t}=\frac{E M}{V}-\lambda C-\alpha C
$$

where $E\left(\mathrm{~Bq} \mathrm{~kg}^{-1} \mathrm{~h}^{-1}\right)$ is the radon-specific exhalation rate, $M(\mathrm{~kg})$ the mass of the sample, $V\left(\mathrm{~m}^{3}\right)$ the air volume of the container, $\lambda\left(\mathrm{h}^{-1}\right)$ the ${ }^{222} \mathrm{Rn}$ or ${ }^{220} \mathrm{Rn}$ decay constant and $\alpha\left(\mathrm{h}^{-1}\right)$ the leakage rate from the container. The bound exhalation rate determined by hermetically closing the sample in a container can be equal to the free exhalation corresponding to the actual room conditions only in the case that the sample volume would be less than the one-tenth of the container volume. Under these circumstances, the 'back diffusion' effect has no influence on exhalation rate measurements (Krisiuk, E.M., Tarasov, S.I., Seamov, V.P., Shalck, N.I., isachenko, E.P., Gomelsky, 1971). The numeric calculation are made by adjusting by least squares of the $\mathrm{C}$ vs $\mathrm{t}$ experimental data to the mathematical function given by equation (3). The $\alpha$ values obtained range approximately from 0.009 to $0.04 \mathrm{~h}-1$. For each material, such $\alpha$ values were considered for the calculation of the 222Rn and 220Rn exhalation.

By solving Equation (2), the radon concentration growth as a function of time is given by:

$$
C(t)=\frac{E M\left[1-e^{-(\lambda+\alpha) t}\right]}{(\lambda+\alpha) V}+C_{0} e^{-(\lambda+\alpha) t}
$$

being $C_{0}\left(\mathrm{~Bq} \mathrm{~m}^{-3}\right)$ the radon concentration at $t=0$.

The ${ }^{222} \mathrm{Rn}$ exhalation $\left(E_{R n 222}\right)$ and $\alpha$ numeric calculation are made by adjusting by least-squares of the $C$ vs $t$ experimental data to the mathematical function given by equation (3). 
However, due to its short half-life, after the first cycle (2 hours) of measurements, the concentration of thoron in the container will reach its maximum value, remaining constant until the end of the measurements. So, from equation (3) the massic thoron exhalation, $E_{R n 220}$, can be calculated from the expression (4), which does not consider $\alpha$ value because it is much smaller than the thoron decay constant, $\lambda_{R n 220}$ :

$$
E_{R n 220}=\frac{C_{R n 220} \lambda_{R n 220} V}{\mathrm{M}}
$$

where $C_{R n 220}\left(\mathrm{~Bq} \mathrm{~m}^{-3}\right)$ is the average concentration of thoron in the container during the interval of measurement from the first cycle of 2 hours.

The emanation factor (amount of radon and thoron atoms that escape from the grains constituting the material into the interstitial space between the grains), $\varepsilon_{R n}$, was calculated by the following equation for both radioisotopes (Stoulos, Manolopoulou \& Papastefanou, 2003):

$$
\varepsilon_{R n}=\frac{E_{R n}}{C_{i} \lambda_{d}}
$$

where $C_{i}$ is the ${ }^{226} \mathrm{Ra}$ or ${ }^{232} \mathrm{Th}$ content $\left(\mathrm{Bq} \mathrm{kg}^{-1}\right)$ of the sample for radon and thoron, respectively, $\lambda_{d}$, the decay constant and $E_{R n}$ the exhalation.

Equation (5) is applicable for all measured building materials, because the dimensions of the samples were chosen to be equal to the diffusion length of these gases for these materials, around $4 \mathrm{~cm}$ (Stoulos, Manolopoulou \& Papastefanou, 2003).

\section{Determination of annual effective dose}

The ${ }^{222} \mathrm{Rn} /{ }^{220} \mathrm{Rn}$ content accumulates in the surrounding air in a dwelling room, from building materials, depends on factors such as the room dimension, the parent element concentration, the subsequent exhalation directly from the soil and building materials in walls or soil (radon gain), the air exchange and the isotope radioactive decay. Therefore, building materials may cause an excess in the indoor ${ }^{222} \mathrm{Rn}$ or ${ }^{220} \mathrm{Rn}$ activity concentrations, which is described by the following equation (Amin, 2015):

$$
A_{R n}=\frac{E_{A} S}{V_{r} \lambda_{v}}
$$


216 where, $A_{R n}$, is the ${ }^{222} \mathrm{Rn}$ or ${ }^{220} \mathrm{Rn}$ activity concentration $\left(\mathrm{Bq} \mathrm{m}^{-3}\right)$ in the air of the room; $E_{A}$ is the 217 surface exhalation rate $\left(\mathrm{Bq} \mathrm{m} \mathrm{m}^{-2} \mathrm{~h}^{-1}\right) ; S$ is the exhalation area $\left(\mathrm{m}^{2}\right) ; V_{r}$ is the volume of the room $218\left(\mathrm{~m}^{3}\right)$ and $\lambda_{v}$ is the ventilation rate of the room $\left(\mathrm{h}^{-1}\right)$. Ratio $\mathrm{S} / \mathrm{V}$ is taken to be 2 and $\lambda_{v}, 0.5 \mathrm{~h}^{-1}($ 219 UNSCEAR, 2016). Considering the value of the sample emanation surface in the container (0.0078 $220 \mathrm{~m}^{2}$; circumference of $\left.5 \mathrm{~cm}^{2}\right)$, and the mass of the sample $(M)$, the surface exhalation rate $\left(E_{A}\right)$ for 221 the building materials can be calculated, using the following equation:

$$
E_{A}=E_{R n} \frac{M}{0.0078}
$$

This radon concentration model can then be used to determinate the annual effective doses of ${ }^{222} \mathrm{Rn}$ by equation (8), recommended by the United Nations Scientific Committee on the Effects of Atomic Radiation (UNSCEAR, 2016):

$$
D_{R n 222}=A_{R n 222} F_{e} T_{a} C F_{R n 222}
$$

where $D_{R n 222}$ is the annual effective dose of ${ }^{222} \mathrm{Rn}\left(\mathrm{Sv} \mathrm{y}^{-1}\right) ; A_{R n 222}$ is the activity concentration for ${ }^{222} \mathrm{Rn}\left(\mathrm{Bq} \mathrm{m}^{-3}\right) ; C F_{R n 222}$ is the dose conversion factor for ${ }^{222} \mathrm{Rn}$ progeny $\left(\mathrm{Sv}\right.$ per $\left.\mathrm{Bq} \mathrm{h} \mathrm{m}{ }^{-3}\right) ; F_{e}$ is the equilibrium factor for ${ }^{222} \mathrm{Rn}$ and its progeny; and $T_{a}$ is the annual work time. The standard parameters were estimated using the RP 122 publication of EC 2002 (European Commission, 2002). The values of $C F_{R n 222}$ were assumed to be $9 \times 10^{-9} \mathrm{~Sv}$ per $\mathrm{Bq} \mathrm{h} \mathrm{m} \mathrm{h}^{-3}$ and the $T_{a}, 7000 \mathrm{~h} \mathrm{y}^{-1}$. The value of $F_{e}$ was assumed to be 0.4 as reported in ( UNSCEAR, 2008).

Similarly, for ${ }^{220} \mathrm{Rn}$ :

$$
D_{R n 220}=A_{R n 220} F_{e} T_{a} C F_{R n 220}
$$

where, $D_{R n 220}$ is the annual effective dose of ${ }^{220} \mathrm{Rn}\left(\mathrm{Sv} \mathrm{y}^{-1}\right) ; A_{R n 220}$ is the activity concentration for ${ }^{220} \mathrm{Rn}\left(\mathrm{Bq} \mathrm{m}^{-3}\right) ; C F_{R n 220}$ is the dose conversion factor for ${ }^{220} \mathrm{Rn}$ progeny $\left(40 \times 10^{-9} \mathrm{~Sv}\right.$ per $\left.\mathrm{Bq} \mathrm{h} \mathrm{m}^{-3}\right)$ and $T_{a}$ is the annual work time, $7000 \mathrm{~h} \mathrm{y}^{-1}$ (European Commission, 2002). $F_{e}$ is the equilibrium factor for ${ }^{220} \mathrm{Rn}$ and its progeny, 0.1 ( UNSCEAR, 2008).

However, since the diffusion length of ${ }^{220} \mathrm{Rn}$ is very short it is complex and ambiguous to calculate the internal exposure due to ${ }^{220} \mathrm{Rn}$ exhaling from the building material. The indoor thoron concentration in air depends on the distance from the wall [21,23] as presented in the following equation: 


$$
A_{R n 220}(X)=\frac{E_{A R n 220}}{\sqrt{\lambda_{R n 220} D_{\text {eff }}}} \exp \left(-\sqrt{\frac{\lambda_{R n 220}}{D_{\text {eff }}}} X\right)
$$

240

241

242

243

244

245

246

247

248

249

250

251

252

253

254

255

256

257

258

259

260

261

262

263

264

265

266

where, $A_{R n 220}(X)$ is the ${ }^{220} \mathrm{Rn}$ concentration at a distance, $X$, from the wall. $E_{A R n 220}$ is the ${ }^{220} \mathrm{Rn}$ estimated surface exhalation rate by equation (7), $D_{e f}$ is the effective diffusion coefficient herein taken as $1.8 \mathrm{~m}^{2} \mathrm{~h}^{-1}[21], \lambda_{R n 220}$ is the decay constant of ${ }^{220} \mathrm{Rn}, 45 \mathrm{~h}^{-1}$.

It is reasonable to assume that the human respiratory organs are not more than $40 \mathrm{~cm}$ distance from the wall. Therefore, the ${ }^{220} \mathrm{Rn}$ concentration at the distance of $40 \mathrm{~cm}$ calculated by equation (10), $A_{R n 220}$, is used to determinate the annual effective doses of ${ }^{220} \mathrm{Rn}$ with equation (9).

\section{Results and discussion}

The results of activity concentration for ${ }^{226} \mathrm{Ra}, C_{R \mathrm{a}}$, massic exhalation, $E_{\mathrm{Rn} 222}$, and emanation factor, $\varepsilon_{\mathrm{Rn} 222}$, for ${ }^{222} \mathrm{Rn}$ are summarised in Table 1 .

In all samples, activity concentration for radium was above the detection limit (DL) except for the wood sample. In general, these results are comparable to those measured in a worldwide scale [2, 45-48]. Thus, the values for radium content in building materials are less than the permissible value $\left(370 \mathrm{~Bq} \mathrm{~kg}^{-1}\right)$, which is acceptable as a safe limit (Group Experts of the OECD Nuclear Energy Agency, 1979). The only exception was in the radium concentration in zircon, the highest value for the mean concentration was $2070 \mathrm{~Bq} \mathrm{~kg}^{-1}$.

In many samples, the exhalation rate was lower than the DL (because of $E_{\mathrm{Rn} 222}<\mathrm{DL}$ ) with exception of all samples of slate, granite and zircon. The maximum value on average was obtained for zircon, $429 \mathrm{mBq} \mathrm{kg}^{-1} \mathrm{~h}^{-1}$, which is much higher than that found for the aggregate and the granites. The values of exhalation rates reported in Table 1 correspond well with the values reported by other authors $[15,50-53]$. The variation in radon exhalation rates (one order of magnitude, in some cases) can be attributed to variations in radium concentrations, porosity, and surface crystallography. The emanation factor range from $0.2 \%$ to $22.0 \%$ for ceramic and aggregates respectively. These values are similar to the measured in worldwide scales $[2,15,46$, 49].

The results of activity concentration for ${ }^{232} \mathrm{Th}, C_{\mathrm{Th}}$, massic exhalation, $E_{\mathrm{Rn} 220}$, and emanation factor, $\varepsilon_{\mathrm{Rn} 220}$, for ${ }^{220} \mathrm{Rn}$ are summarised in Table 2 . 
The highest mean value for ${ }^{232} \mathrm{Th}$ activity concentration is shown by zircon $\left(340 \mathrm{~Bq} \mathrm{~kg}^{-1}\right)$, and the lowest mean value is obtained for wood $\left(0.6 \mathrm{~Bq} \mathrm{~kg}^{-1}\right)$. The mean values of the ${ }^{220} \mathrm{Rn}$ massic exhalation rate range from 2.2 of the ceramic to $169 \mathrm{~Bq} \mathrm{~kg}^{-1} \mathrm{~h}^{-1}$ for zircon, respectively. The results show that the thoron exhalation rate is higher in zircon samples and lower in ceramic samples. This can presumably be explained by the different distributions of ${ }^{224} \mathrm{Ra}$ parent element in the different types of samples. It should be noted how the difference among the values of exhalation rate in granites (range from 2.6 to $144 \mathrm{~Bq} \mathrm{~kg}^{-1} \mathrm{~h}^{-1}$ ) reveal their different mineralogical composition. The emanation factor range from $0.3 \%$ to $29 \%$ for ceramic and wood, respectively.

The ranges of results of all these parameters are in good agreement with the values reports by other authors $[29,54]$.

A correlation study of ${ }^{222} \mathrm{Rn}$ mass exhalation rate with respect to ${ }^{226} \mathrm{Ra}$ content, as shown in Fig. 4a, showed a good linear correlation coefficient $\left(\mathrm{R}^{2}=0.9961\right)$. These results show that the ${ }^{222} \mathrm{Rn}$ mass exhalation rate increases as the ${ }^{226} \mathrm{Ra}$ content is higher in the samples. This good linear correlation has already been observed by other authors, some of them with values very close to 1 (Amin, 2015). As could be expected (Fig. 4b), no correlation $\left(\mathrm{R}^{2}=0.0109\right)$ was found between the ${ }^{222} \mathrm{Rn}$ emanation factor and the ${ }^{226} \mathrm{Ra}$ content.

A similar correlation of ${ }^{220} \mathrm{Rn}$ mass exhalation rate with ${ }^{232} \mathrm{Th}$ content is shown in Fig. 5a, which shows a more weak correlation between the two quantities $\left(\mathrm{R}^{2}=0.8336\right)$. These results show that the ${ }^{220} \mathrm{Rn}$ mass exhalation rate increases for samples with higher ${ }^{232} \mathrm{Th}$ contents, as observed before for the ${ }^{222} \mathrm{Rn}$ exhalation rate and ${ }^{226} \mathrm{Ra}$ contents.

Moreover, as could be expected (Fig. 5b), no correlation $\left(\mathrm{R}^{2}=0.0115\right)$ was found between the ${ }^{220} \mathrm{Rn}$ emanation factor and the ${ }^{232} \mathrm{Th}$ content. Finally, no correlation $\left(\mathrm{R}^{2}=0.118\right)$ was found between the ${ }^{222} \mathrm{Rn}$ emanation factor and the ${ }^{220} \mathrm{Rn}$ emanation factor as shown in Fig. 5c.

The results obtained for indoor contribution, surface exhalation rate, activity concentration in the air of the room, and annual effective dose, for the different building materials had been shown in Tables 3 and 4 for ${ }^{222} \mathrm{Rn}$ and ${ }^{220} \mathrm{Rn}$, respectively. Therefore, Table 3 shows that the mean values of ${ }^{222} \mathrm{Rn}$ surface exhalation rates varied from 9.2 to $3206 \mathrm{mBq} \mathrm{m}^{-2} \mathrm{~h}^{-1}$ for ceramic and zircon, respectively. The ${ }^{222} \mathrm{Rn}$ contribution of building materials to indoor ${ }^{222} \mathrm{Rn}$ considering the model room mentioned above, range from 0.04 for ceramic samples to $13 \mathrm{~Bq} \mathrm{~m}^{-3}$ for zircon. As a result of this, the annual effective dose ranged from $0.9 \mu \mathrm{Sv} \mathrm{y}^{-1}$ for ceramic to $323 \mu \mathrm{Sv} \mathrm{y}^{-1}$ for zircon. These values are in agreement with the worldwide range $[2,55]$. 
In the case of ${ }^{220} \mathrm{Rn}$ (see Table 4), the surface exhalation rate average varied from 22 to 1264 $\mathrm{Bq} \mathrm{m}^{-2} \mathrm{~h}^{-1}$ for cement and zircon respectively. Its contribution of building materials to indoor ${ }^{220} \mathrm{Rn}$ at $40 \mathrm{~cm}$ of the wall considering the model mentioned above, range from 2.0 for the cement to 112 $\mathrm{Bq} \mathrm{m}^{-3}$ for zircon. Mean values of the annual effective dose ranged from $16 \mu \mathrm{Sv} \mathrm{y}^{-1}$ for gypsum to $1300 \mu \mathrm{Sv} \mathrm{y}^{-1}$ for zircon. These values are similar to those found by other authors for building materials (Ujić et al., 2010). However, estimation of annual effective dose from indoor thoron indicated the mean value of zircon and some values of granites had been higher than the annual exposure limit for the general public of $1 \mathrm{mSv} \mathrm{y}{ }^{-1}$, recommended by European Directive 2013/59/Euratom [40].

\section{Conclusions}

In this study, the radon and thoron exhalation and emanation properties of building materials commonly used in the Iberian Peninsula (Portugal and Spain) were measured by using an active method with a continuous radon/thoron monitor. The correlations between exhalation rates of these gases and their parent nuclide exhalation (radium/thorium) concentrations were examined. Finally, on estimation the indoor radon/thoron, the annual effective dose was calculated.

In general, ${ }^{226} \mathrm{Ra}$ content in building materials is less than the permissible value, $370 \mathrm{~Bq} \mathrm{~kg}^{-1}$, except for zircon, which means value was $2100 \mathrm{~Bq} \mathrm{~kg}^{-1}$. For this material the maximum value on average of ${ }^{222} \mathrm{Rn}$ massic exhalation rate $\left(429 \mathrm{mBq} \mathrm{kg}^{-1} \mathrm{~h}^{-1}\right)$ was also obtained. The emanation factor ${ }^{222} \mathrm{Rn} /{ }^{226} \mathrm{Ra}$ ranges from $0.2 \%$ to $22.0 \%$ for ceramic and aggregates, respectively. On average, the highest value for activity concentration of ${ }^{232} \mathrm{Th}$ and massic ${ }^{220} \mathrm{Rn}$ exhalation rate were showed by zircon, $340 \mathrm{~Bq} \mathrm{~kg}{ }^{-1}$ and $169 \mathrm{~Bq} \mathrm{~kg}^{-1} \mathrm{~h}^{-1}$, respectively. The emanation factor of ${ }^{220} \mathrm{Rn}^{232} \mathrm{Th}$ range from $0.3 \%$ to $29 \%$ for ceramic and wood, respectively. The correlation between the radon mass exhalation rate and the ${ }^{226} \mathrm{Ra}$ contents as well as the correlation between the thoron mass exhalation rate and ${ }^{232} \mathrm{Th}$ contents are in good agreement.

The mean values of ${ }^{222} \mathrm{Rn}$ surface exhalation rates varied from 9.2 to $3206 \mathrm{mBq} \mathrm{m}^{-2} \mathrm{~h}^{-1}$ for ceramic and zircon, respectively. The ${ }^{222} \mathrm{Rn}$ contribution of building materials to indoor ${ }^{222} \mathrm{Rn}$ considering the model room mentioned above, range from 0.04 for ceramic samples to $13 \mathrm{~Bq} \mathrm{~m}^{-3}$ for zircon. So, the annual effective dose ranged from $0.9 \mu \mathrm{Sv}^{-1}$ for ceramic to $323 \mu \mathrm{Sv} \mathrm{y}^{-1}$ for zircon. 
In the case of ${ }^{220} \mathrm{Rn}$, the surface exhalation rate average varied from 22 to $1264 \mathrm{~Bq} \mathrm{~m}^{-2} \mathrm{~h}^{-1}$ for cement and zircon respectively. Its contribution of building materials to indoor ${ }^{220} \mathrm{Rn}$ at $40 \mathrm{~cm}$ of the wall, range from 2.0 for cement samples to $112 \mathrm{~Bq} \mathrm{~m}^{-3}$ for zircon. Mean values of the annual effective dose ranged from $16 \mu \mathrm{Sv} \mathrm{y}^{-1}$ for gypsum to $1300 \mu \mathrm{Sv} \mathrm{y}^{-1}$ for zircon. Therefore, in the case of zircon and some granites, the annual effective dose was higher than the annual exposure limit for the general public of $1 \mathrm{mSv} \mathrm{y}^{-1}$, recommended by the ICRP.

\section{Acknowledgements}

We acknowledge Junta de Extremadura, Spain (projects PRI IB16114), the Air Quality Surveillance Network of Extremadura (REPICA, project 1855999FD022) for financial support, and European Union Funds for Regional Development (FEDER).

The authors of the "Centro de Ciências e Tecnologias Nucleares" (C2TN) of "Instituto Superior Técnico" (IST) gratefully acknowledge the Foundation for Science and Technology (FCT) in Portugal for the support through the ID/Multi/04349/2013 project.

\section{References}

Amin RM. 2015. A study of radon emitted from building materials using solid state nuclear track detectors. Journal of Radiation Research and Applied Sciences 8:516-522. DOI: 10.1016/j.jrras.2015.06.001.

Andrade E, Miró C, Reis M, Santos M, Madruga MJ. 2017. Assessment of Radium Activity Concentration and Radon Exhalation Rates in Iberian Peninsula Building Materials. Radiation Protection Dosimetry:1-5. DOI: 10.1093/rpd/ncx128.

Bavarnegin E, Fathabadi N, Vahabi Moghaddam M, Vasheghani Farahani M, Moradi M, Babakhni A. 2013. Radon exhalation rate and natural radionuclide content in building materials of high background areas of Ramsar, Iran. Journal of Environmental Radioactivity 117:36-40. DOI: 10.1016/j.jenvrad.2011.12.022.

Brenner DJ. 1994. ICRP (International Commission on Radiological Protection). Protection Against Radon-222 at Home and at Work (ICRP Publication No 65). Annals of the ICRP 23. DOI: 10.1080/09553009414551371.

Chen CJ, Lin YM. 1997. Assessment of building materials for compliance with regulations of ROC. Environment International 22:221-226. DOI: 10.1016/S0160-4120(96)00111-0.

Chen J, Rahman NM, Atiya IA. 2010. Radon exhalation from building materials for decorative use. Journal of Environmental Radioactivity 101:317-322. DOI: 10.1016/j.jenvrad.2010.01.005.

Chitra N, Danalakshmi B, Supriya D, Vijayalakshmi I, Sundar SB, Sivasubramanian K, Baskaran R, Jose MT. 2018. Study of Radon and Thoron exhalation from soil samples of different grain sizes. Applied Radiation and Isotopes 133:75-80. DOI: 10.1016/j.apradiso.2017.12.017. 
Directive. 2013/59/Euratom of 5 December 2013. 2014. Official Journal of the European Union 57:1-73. DOI: doi:10.3000/19770677.L_2013.124.eng.

Doi M, Fujimoto K, Kobayashi S, Yonehara H. 1994. Spatial Distribution of Thoron and Radon Concentrations in the Indoor Air of A Traditional Japanese Wooden House. Health Physics 66.

European Commission. 2002. Radiation protection 122 practical use of the concepts of clearance and exemption(Part II).

Frutos-Puerto S, Pinilla-Gil E, Miró C, Andrade E, Reis M, José Madruga M. 2018. Exhalation Rate Study of Thoron in Some Building Materials of the Iberian Peninsula. Proceedings 2:1294. DOI: $10.3390 /$ proceedings2201294.

Group Experts of the OECD Nuclear Energy Agency. 1979. OECD (1979) Exposure to radiation from the natural radioactivity in building materials. : 40 .

Hafez AF, Hussein AS, Rasheed NM. 2001. A study of radon and thoron release from Egyptian building materials using polymeric nuclear track detectors. Applied Radiation and Isotopes 54:291-298. DOI: 10.1016/S0969-8043(00)00281-5.

Hassan NM, Hosoda M, Iwaoka K, Sorimachi A, Janik M, Kranrod C, Sahoo SK, Ishikawa T, Yonehara H, Fukushi M, Tokonami S. 2011. Simultaneous Measurment of Radon and Thoron Released from Building Materials Used in Japan. Progress in Nuclear Sciencie and Technology 1:404-407.

Iwaoka K, Hosoda M, Suwankot N, Omori Y, Ishikawa T, Yonehara H, Tokonami S. 2015. Natural radioactivity and radon exhalation rates in man-made tiles used as building materials in Japan. Radiation Protection Dosimetry 167:135-138. DOI: $10.1093 / \mathrm{rpd} / \mathrm{ncv} 230$.

Jónás J, Sas Z, Vaupotic J, Kocsis E, Somlai J, Kovács T. 2016. Thoron emanation and exhalation of Slovenian soils determined by a PIC detector-equipped radon monitor. Nukleonika 61:379-384. DOI: 10.1515/nuka-2016-0063.

Kanse SD, Sahoo BK, Sapra BK, Gaware JJ, Mayya YS. 2013. Powder sandwich technique: A novel method for determining the thoron emanation potential of powders bearing high224Ra content. Radiation Measurements 48:82-87. DOI: 10.1016/j.radmeas.2012.10.014.

Kayakökü H, Karatepe Ş, Doğru M. 2016. Measurements of radioactivity and dose assessments in some building materials in Bitlis, Turkey. Applied Radiation and Isotopes 115:172-179. DOI: 10.1016/j.apradiso.2016.06.020.

Krisiuk, E.M., Tarasov, S.I., Seamov, V.P., Shalck, N.I., isachenko, E.P., Gomelsky L. 1971. A Study of Radioactivity of Building Materials. Leningrad Research Institute for Radiation Hygiene.

Kudo H, Tokonami S, Omori Y, Ishikawa T, Iwaoka K, Sahoo SK, Akata N, Hosoda M, Wanabongse P, Pornnumpa C, Sun Q, Li X, Akiba S. 2015. Comparative dosimetry for radon and thoron in high background radiation areas in China. Radiation Protection Dosimetry 167:155-159. DOI: 10.1093/rpd/ncv235.

Kumar A, Chauhan RP, Joshi M, Prajith R, Sahoo BK. 2015. Estimation of radionuclides content and radon-thoron exhalation from commonly used building materials in India. Environmental Earth Sciences 74:1539-1546. DOI: 10.1007/s12665-015-4146-8.

López-Coto I, Mas JL, Vargas A, Bolívar JP. 2014. Studying radon exhalation rates variability from phosphogypsum piles in the SW of Spain. Journal of Hazardous Materials 280:464471. DOI: 10.1016/j.jhazmat.2014.07.025. 
412

413

414

415

416

417

418

419

420

421

422

423

424

425

426

427

428

429

430

431

432

433

434

435

436

437

438

439

440

441

442

443

444

445

446

447

448

449

450

451

452

453

454

455

456

457

Madruga MJ, Miró C, Reis M, Silva L. 2018. Radiation Exposure From Natural Radionuclides in Building Materials. Radiation Protection Dosimetry:1-9. DOI: 10.1093/rpd/ncy256.

Maged AF, Ashraf FA. 2005. Radon exhalation rate of some building materials used in Egypt. Environmental Geochemistry and Health 27:485-489. DOI: 10.1007/s10653-005-5332-5.

Magnoni M, Chiaberto E, Prandstatter A, Serena E, Tripodi R. 2018. Thoron exhalation rate in stony materials: A simplified approach. Construction and Building Materials 173:520-524. DOI: 10.1016/j.conbuildmat.2018.04.053.

Mehta V, Singh PS, Chauhan PR, Mudahar GS. 2015. Study of indoor radon, thoron, their progeny concentration and radon exhalation rate in the environs of Mohali, Punjab, Northern India. Aerosol and Air Quality Research 15:1380-1389. DOI: 10.4209/aaqr.2014.08.0161.

Merešová J, Wätjen U, Altzitzoglou T. 2012. Determination of natural and anthropogenic radionuclides in soil-results of an European Union comparison. Applied Radiation and Isotopes 70:1836-1842. DOI: 10.1016/j.apradiso.2012.02.017.

Milić G, Jakupi B, Tokonami S, Trajković R, Ishikawa T, Čeliković I, Ujić P, Čuknić O, Yarmoshenko I, Kosanović K, Adrović F, Sahoo SK, Veselinović N, Žunić ZS. 2010. The concentrations and exposure doses of radon and thoron in residences of the rural areas of Kosovo and Metohija. Radiation Measurements 45:118-121. DOI: 10.1016/j.radmeas.2009.10.052.

Miro C, Andrade E, Reis M, Madruga MJ. 2014. Development of a couple of methods for measuring radon exhalation from building materials commonly used in the Iberian Peninsula. Radiation Protection Dosimetry 160:177-180. DOI: 10.1093/rpd/ncu063.

Misdaq MA, Amghar A. 2005. Radon and thoron emanation from various marble materials: Impact on the workers. Radiation Measurements 39:421-430. DOI: 10.1016/j.radmeas.2004.06.011.

Netherlands Standardization Institute. Dutch Standard: Radioactivity measurement. Determination method of the rate of the radon exhalation of dense building materials. 2001. :NEN 5699:2001.

Perna AFN, Paschuk SA, Corrêa JN, Narloch DC, Barreto RC, Del Claro F, Denyak V. 2018. Exhalation rate of radon-222 from concrete and cement mortar. Nukleonika 63:65-72. DOI: 10.2478/nuka-2018-0008.

Petropoulos NP, Anagnostakis MJ, Simopoulos SE. 2001. Building materials radon exhalation rate: ERRICCA intercomparison exercise results. Science of the Total Environment 272:109-118. DOI: 10.1016/S0048-9697(01)00674-X.

Porstendörfer J. 1994. Properties and behaviour of radon and thoron and their decay products in the air. Journal of Aerosol Science 25:219-263. DOI: 10.1016/0021-8502(94)90077-9.

Prajith R, Rout RP, Kumbhar D, Mishra R, Sahoo BK, Sapra BK. 2019. Measurements of radon $(222 \mathrm{Rn})$ and thoron $(220 \mathrm{Rn})$ exhalations and their decay product concentrations at Indian Stations in Antarctica. Environmental Earth Sciences 78:35. DOI: 10.1007/s12665-0188029-7.

Rawat A, Jojo PJ, Khan AJ, Tyagi RK, Prasad R. 1991. Radon exhalation rate in building materials. International Journal of Radiation Applications and Instrumentation. Part 19:391-394. DOI: 10.1016/1359-0189(91)90223-5.

Righi S, Bruzzi L. 2006. Natural radioactivity and radon exhalation in building materials used in Italian dwellings. Journal of Environmental Radioactivity 88:158-170. DOI: 10.1016/j.jenvrad.2006.01.009. 
458

Saad AF, Al-Awami HH, Hussein NA. 2014. Radon exhalation from building materials used in Libya. Radiation Physics and Chemistry 101:15-19. DOI: 10.1016/j.radphyschem.2014.03.030.

Sabiha-Javied, Tufail M, Asghar M. 2010. Hazard of NORM from phosphorite of Pakistan. Journal of Hazardous Materials 176:426-433. DOI: 10.1016/j.jhazmat.2009.11.047.

Semwal P, Singh K, Agarwal TK, Joshi M, Pant P, Kandari T, Ramola RC. 2018. Measurement of 222Rn and 220Rn exhalation rate from soil samples of Kumaun Hills, India. Acta Geophysica 66:1203-1211. DOI: 10.1007/s11600-018-0124-3.

Sharma N, Virk HS. 2001. Exhalation rate study of radon/thoron in some building materials. Radiation Measurements 34:467-469. DOI: 10.1016/S1350-4487(01)00208-6.

Sola P, Srinuttrakul W, Laoharojanaphand S, Suwankot N. 2014. Estimation of indoor radon and the annual effective dose from building materials by ionization chamber measurement. Journal of Radioanalytical and Nuclear Chemistry 302:1531-1535. DOI: 10.1007/s10967014-3716-7.

Stoulos S, Manolopoulou M, Papastefanou C. 2003. Assessment of natural radiation exposure and radon exhalation from building materials in Greece. Journal of Environmental Radioactivity 69:225-240. DOI: 10.1016/S0265-931X(03)00081-X.

Turhan Ş, Gündüz L. 2008. Determination of specific activity of226Ra,232Th and40K for assessment of radiation hazards from Turkish pumice samples. Journal of Environmental Radioactivity 99:332-342. DOI: 10.1016/j.jenvrad.2007.08.022.

Turhan S, T. Termici A, Kurnaz A, Altikulak A, Goren E, Karatasli M, Kirisik R, Hancerliogullari A. 2018. Natural radiation exposure and radon exhalation rate of building materials used in turkey. Nuclear Technology \& Radiation Protection 33:159-166.

Ujić P, Čeliković I, Kandić A, Vukanac I, Durašević M, Dragosavac D, Žunić ZS. 2010. Internal exposure from building materials exhaling 222Rn and 220Rn as compared to external exposure due to their natural radioactivity content. Applied Radiation and Isotopes 68:201206. DOI: 10.1016/j.apradiso.2009.10.003.

United Nations Scientific Committee on the Effects of Ionisin Radiation (UNSCEAR), Sources, Effects and Risks of Ionizing Radiation, Report to the General Assembly. 1988.

United Nations Scientific Committee on the Effects of Ionisin Radiation (UNSCEAR), Sources, Effects and Risks of Ionizing Radiation, Report to the General Assembly. 1993.

United Nations Scientific Committee on the Effects of Ionisin Radiation (UNSCEAR), Sources, Effects and Risks of Ionizing Radiation, Report to the General Assembly. 2008. New York.

United Nations Scientific Committee on the Effects of Ionisin Radiation (UNSCEAR), Sources, Effects and Risks of Ionizing Radiation, Report to the General Assembly. 2016. New York.

de With G, de Jong P. 2011. CFD modelling of thoron and thoron progeny in the indoor environment. Radiation Protection Dosimetry 145:138-144.

De With G, De Jong P, Röttger A. 2014. Measurement of thoron exhalation rates from building materials. Health Physics 107:206-212. DOI: 10.1097/HP.0000000000000105.

de With G, Smetsers RCGM, Slaper H, de Jong P. 2018. Thoron exposure in Dutch dwellings An overview. Journal of Environmental Radioactivity 183:73-81. DOI: 10.1016/j.jenvrad.2017.12.014.

World Health Organization. 1988. IARC Monographs on the Evaluation of the Carcinogenic Risks to Humans.

World Health Organization. 2009. Indoor Radon a Public Health Perspective. Geneva: WHO Press. 
504

505

506

507

508

509

510

511

Xhixha G, Trinidad JA, Gascó C, Mantovani F. 2017. First intercomparison among laboratories involved in COST Action-TU1301 "NORM4Building": Determination of natural radionuclides in ceramics. Journal of Environmental Radioactivity 168:4-9. DOI: 10.1016/j.jenvrad.2016.03.007.

Zhang L, Lei X, Guo Q, Wang S, Ma X, Shi Z. 2012. Accurate measurement of the radon exhalation rate of building materials using the closed chamber method. Journal of Radiological Protection 32:315-323. DOI: 10.1088/0952-4746/32/3/315. 
Figure 1

Figure 1. Origin of the building materials. A) NM materials: 1) Concrete, 2) Cement, 3) Marble, 4) Slate, 5) Granite, 6) Ceramic, 7) Wood, 8) Aggregate, 9) Zircon. B) PM materials: 10) Gypsum.

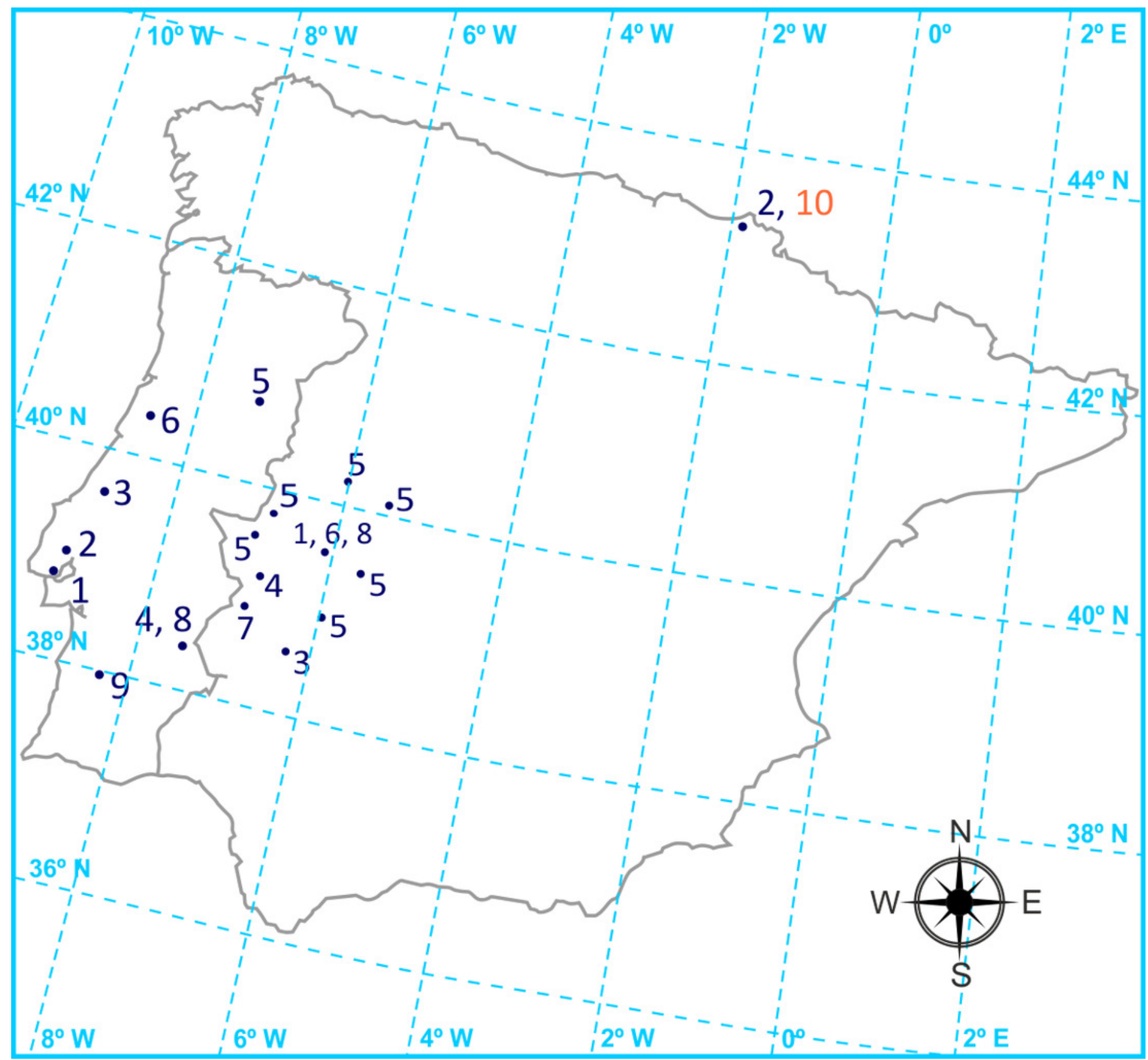


Figure 2

Figure 2. Gamma-ray spectrum of a granite sample.

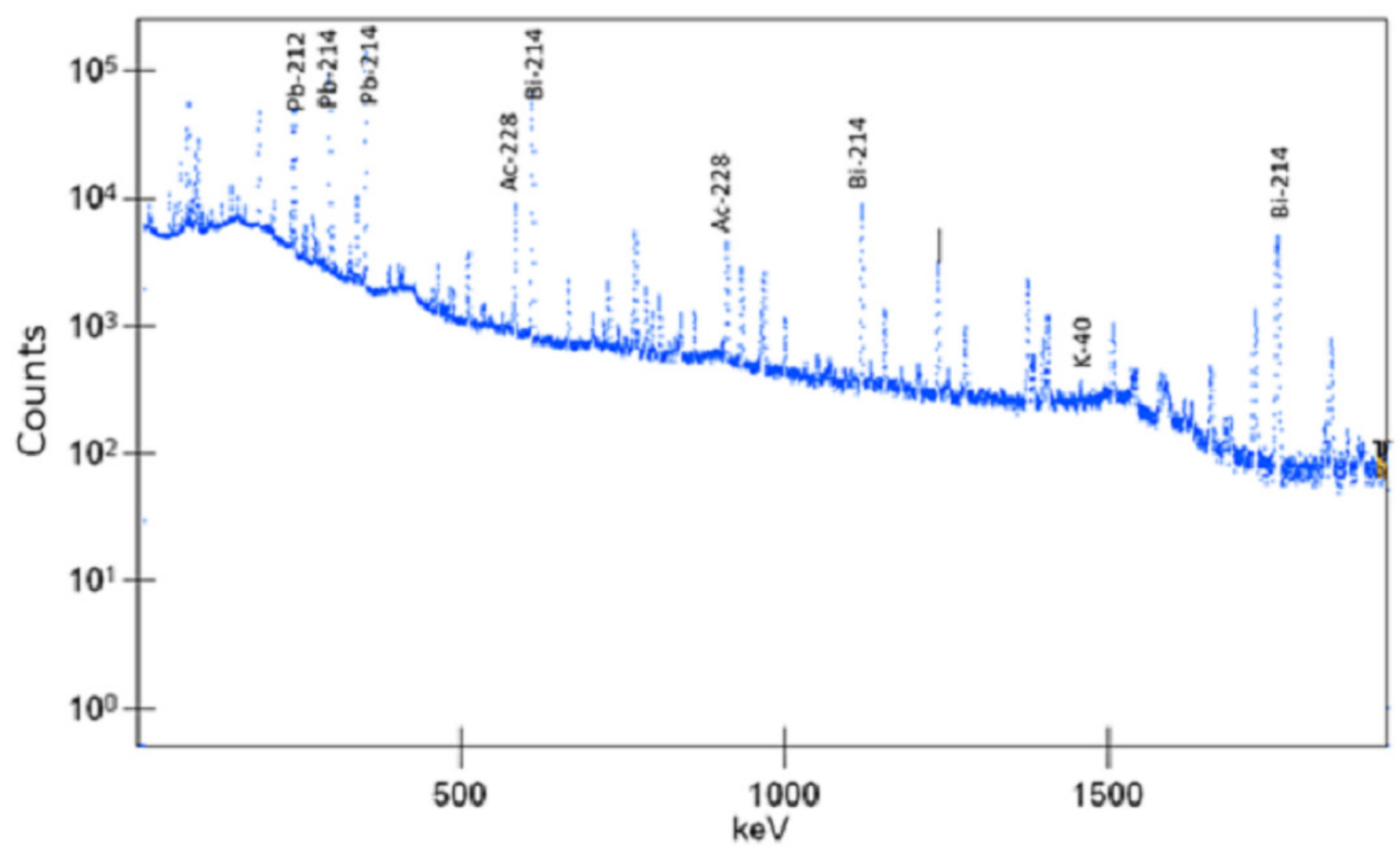


Figure 3

Figure 3. Schematic experimental set-up for the radon/thoron concentration measurements.

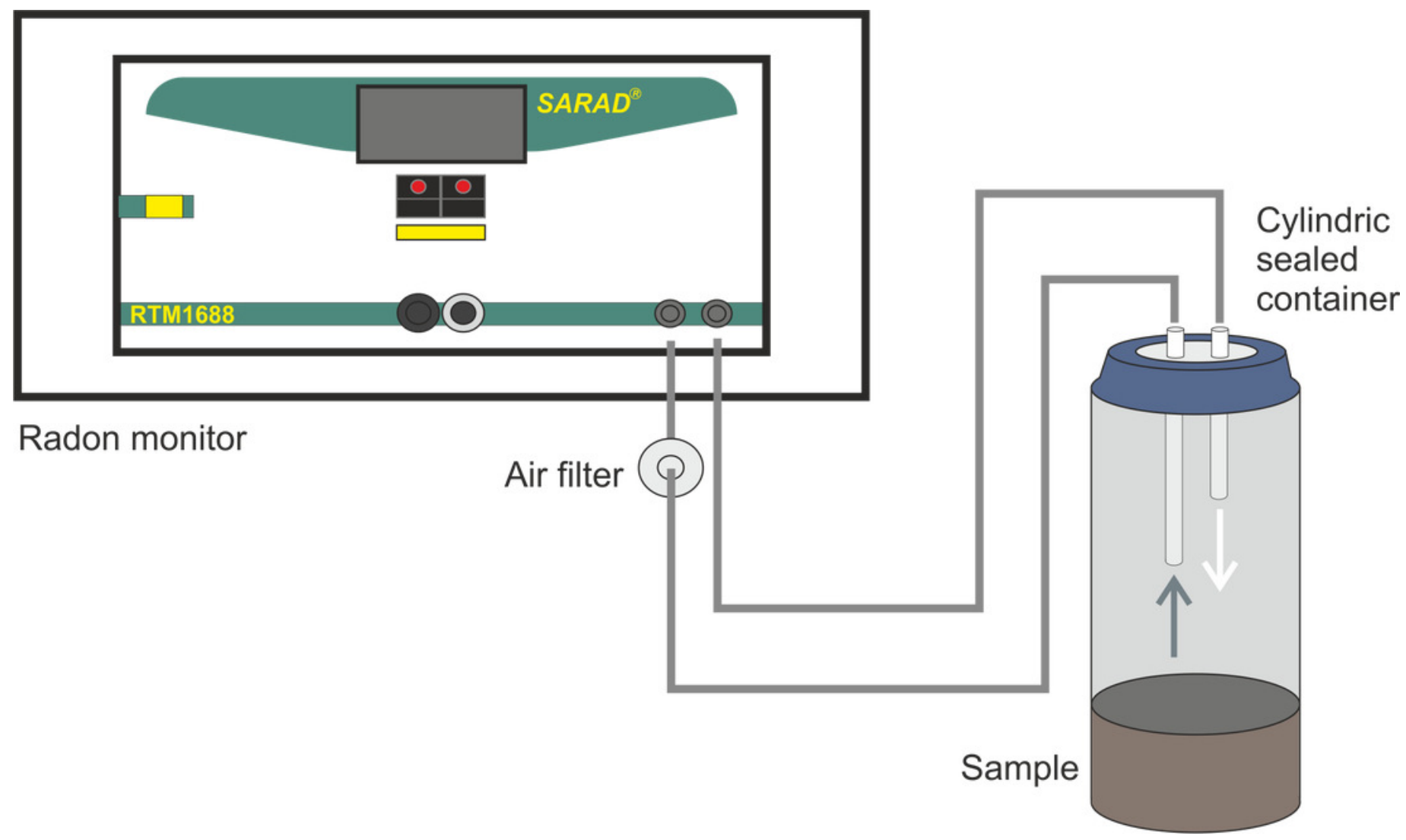


Figure 4

Figure 4. Linear correlation analysis between ${ }^{226} \mathrm{Ra}$ content and (a) ${ }^{222} \mathrm{Rn}$ mass exhalation rate, and (b) ${ }^{222} \mathrm{Rn}$ emanation factor
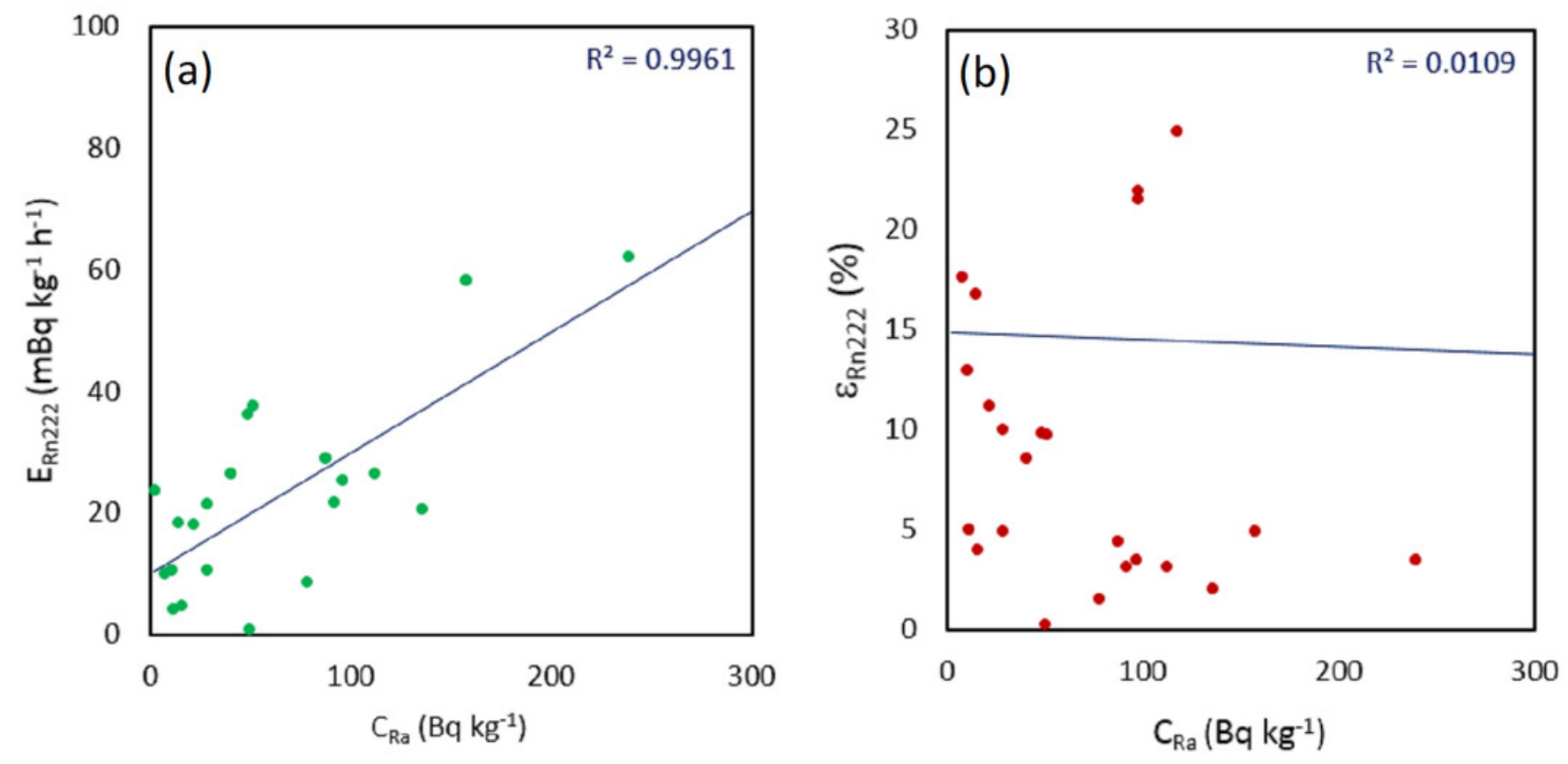
Figure 5

Figure 5. Linear correlation analysis between ${ }^{223} \mathrm{Th}$ content and (a) ${ }^{220} \mathrm{Rn}$ mass exhalation rate, (b) ${ }^{220} \mathrm{Rn}$ emanation factor. (c) Correlation analysis between the ${ }^{222} \mathrm{Rn}$ and ${ }^{220} \mathrm{Rn}$ emanation factors.
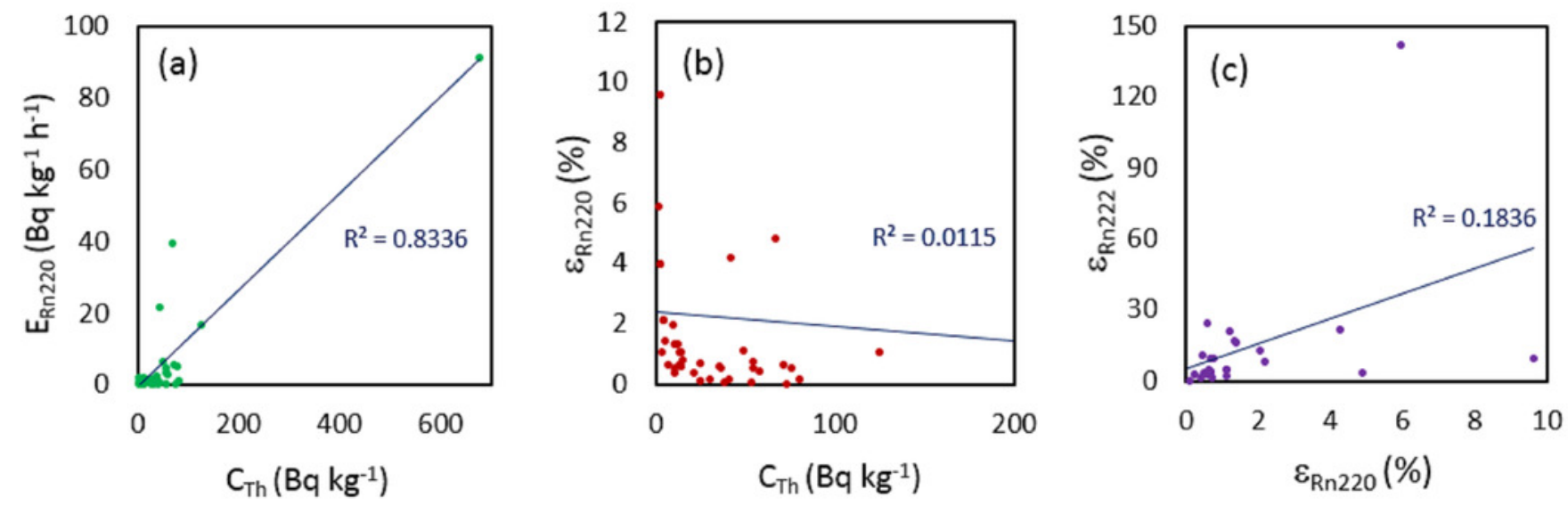


\section{Table $\mathbf{1}$ (on next page)}

Table 1: Activity concentration for ${ }^{226} \mathrm{Ra}, C_{\mathrm{Ra}}$, massic exhalation, $E_{\mathrm{Rn} 222}$, and emanation factor, $\varepsilon_{\mathrm{Rn} 222}$, for ${ }^{222} \mathrm{Rn}$ of different building materials. 


\begin{tabular}{|c|c|c|c|c|c|c|c|c|c|c|c|}
\hline \multirow{2}{*}{\multicolumn{2}{|c|}{$\begin{array}{l}\text { Building } \\
\text { materials }\end{array}$}} & \multirow{2}{*}{$\begin{array}{c}\begin{array}{c}\text { No. of } \\
\text { samples } \\
\left(E_{\mathrm{Rn} 222}>\mathrm{DL}\right.\end{array} \\
\end{array}$} & \multicolumn{3}{|c|}{$C_{\mathrm{Ra}}\left(\mathrm{Bq} \mathrm{kg}{ }^{-1}\right)$} & \multicolumn{3}{|c|}{$E_{\mathrm{Rn} 222}\left(\mathrm{mBq} \mathrm{kg}^{-1} \mathrm{~h}^{-1}\right)$} & \multicolumn{3}{|c|}{$\varepsilon_{\mathrm{Rn222}}(\%)$} \\
\hline & & & Mean & SD & Range & Mean & SD & Range & Mean & SD & Range \\
\hline \multirow{9}{*}{ NM } & Concrete & $9(7)$ & 27.0 & 31.8 & $7.6-87.3$ & 12.2 & 8.7 & $4.3-29.0$ & 8.9 & 6.7 & $1.5-17.6$ \\
\hline & Cement & $5(1)$ & 28.2 & 25.1 & $21.5-76.6$ & 21.0 & 3.9 & $18.4-23.8$ & 11.2 & - & - \\
\hline & Marble & $2(1)$ & 22.8 & 25.3 & $4.9-40.7$ & 26.3 & - & - & 8.6 & - & - \\
\hline & Slate & $2(2)$ & 28.7 & 0.2 & $28.6-28.9$ & 16.0 & 97.4 & $10.4-21.6$ & 7.4 & 3.6 & $4.9-9.9$ \\
\hline & Granite & $9(9)$ & 122.2 & 52.9 & $51.0-239.1$ & 70.3 & 71.4 & $20.5-221.4$ & 8.5 & 8.7 & $2.0-24.9$ \\
\hline & Ceramic & $7(1)$ & 126.4 & 105.8 & $49.9-335.0$ & 0.7 & - & - & 0.2 & - & - \\
\hline & Wood & $1(0)$ & - & - & - & - & - & - & - & - & - \\
\hline & Aggregate & $2(1)$ & 69.9 & 39.7 & $41.8-97.9$ & 162.5 & - & - & 22.0 & - & - \\
\hline & Zircon & $2(2)$ & 2070 & 14.4 & $48.7-4090.0$ & 429.5 & 16.4 & $36.0-823.0$ & 6.2 & 5.0 & $2.7-9.8$ \\
\hline PM & Gypsum & $2(1)$ & 4.4 & 3.1 & $2.2-6.6$ & 1.4 & - & - & 142.6 & - & - \\
\hline
\end{tabular}




\section{Table 2 (on next page)}

Table 2: Activity concentration for ${ }^{232} \mathrm{Th}, C_{\mathrm{Th}}$, massic exhalation, $E_{\mathrm{Rn} 220}$, and emanation factor, $\varepsilon_{\mathrm{Rn} 220}$, for ${ }^{220} \mathrm{Rn}$ of different building materials. 


\begin{tabular}{|c|c|c|c|c|c|c|c|c|c|c|c|}
\hline \multirow{2}{*}{\multicolumn{2}{|c|}{ Building materials }} & \multirow{2}{*}{ No. of samples } & \multicolumn{3}{|c|}{$C_{\mathrm{Th}}\left(\mathrm{Bq} \mathrm{kg} \mathbf{~ k}^{-1}\right)$} & \multicolumn{3}{|c|}{$E_{\mathrm{Rn} 220}\left(\mathrm{~Bq} \mathrm{~kg}{ }^{-1} \mathrm{~h}^{-1}\right)$} & \multicolumn{3}{|c|}{$\varepsilon_{\text {Rn220 }}(\%)$} \\
\hline & & & Mean & SD & Range & Mean & SD & Range & Mean & SD & Range \\
\hline \multirow{9}{*}{ NM } & Concrete & 9 & 14 & 9.8 & $3.9-35$ & 6.3 & 2.4 & $1.9-10$ & 1.2 & 0.6 & $0.6-2.1$ \\
\hline & Cement & 6 & 9.2 & 5.5 & $1.1-14$ & 3.4 & 1.3 & $1.7-5.4$ & 1.6 & 0.6 & $0.4-5.9$ \\
\hline & Marble & 2 & 2.9 & 1.4 & $1.8-3.9$ & 3.5 & 0.3 & $3.3-3.8$ & 3.1 & 1.3 & $2.2-4.0$ \\
\hline & Slate & 2 & 73 & 2.9 & $71-75$ & 20 & 2.7 & $20-21$ & 0.6 & 0.1 & $0.6-0.7$ \\
\hline & Granite & 9 & 51 & 33 & $10-124$ & 31 & 46 & $2.6-144$ & 1.1 & 1.4 & $0.2-4.8$ \\
\hline & Ceramic & 7 & 43 & 27 & $3.1-80$ & 2.2 & 1.6 & $1.5-5.8$ & 0.3 & 0.4 & $0.0-1.1$ \\
\hline & Wood & 1 & 0.6 & - & - & 78 & - & - & 29 & - & - \\
\hline & Aggregate & 2 & 47 & 30 & $41-54$ & 11 & 3.6 & $7.8-13$ & 2.4 & 2.6 & $0.5-4.2$ \\
\hline & Zircon & 2 & 340 & 21 & $1.6-676$ & 169 & 228 & $6.9-330$ & 5.4 & 6.0 & $1.1-9.6$ \\
\hline $\mathrm{PM}$ & Gypsum & 1 & 1.4 & - & - & 2.7 & 0.3 & $2.5-2.9$ & 4.0 & - & - \\
\hline
\end{tabular}




\section{Table 3(on next page)}

Table 3: ${ }^{222} \mathrm{Rn}$ surface exhalation rate, $E_{\mathrm{A}}$, activity concentrationi in the air of the room, $A_{\text {Rn222, }}$ and annual effective dose, $D_{\text {Rn222 }}$, for the different building materials. 
1

\begin{tabular}{|c|c|c|c|c|c|c|c|c|c|c|c|}
\hline \multirow{2}{*}{\multicolumn{2}{|c|}{ Building materials }} & \multirow{3}{*}{$\begin{array}{c}\text { No. of samples } \\
9(7)\end{array}$} & \multicolumn{3}{|c|}{ 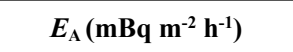 } & \multicolumn{3}{|c|}{$A_{R n 222}\left(\mathrm{~Bq} \mathrm{~m}^{-3}\right)$} & \multicolumn{3}{|c|}{$D_{\mathrm{Rn} 222}\left(\mu \mathrm{Sv} \mathrm{y}^{-1}\right)$} \\
\hline & & & \multirow{2}{*}{$\begin{array}{c}\text { Mean } \\
85\end{array}$} & \multirow{2}{*}{$\begin{array}{l}\text { SD } \\
47\end{array}$} & \multirow{2}{*}{$\begin{array}{c}\text { Range } \\
43-169\end{array}$} & \multirow{2}{*}{$\begin{array}{c}\text { Mean } \\
0.34\end{array}$} & \multirow{2}{*}{$\frac{\text { SD }}{0.19}$} & \multirow{2}{*}{$\begin{array}{c}\text { Range } \\
0.17-0.67\end{array}$} & \multirow{2}{*}{$\begin{array}{c}\text { Mean } \\
8.6\end{array}$} & \multirow{2}{*}{$\begin{array}{l}\text { SD } \\
4.7\end{array}$} & \multirow{2}{*}{$\begin{array}{c}\text { Range } \\
4.3-17\end{array}$} \\
\hline & Concrete & & & & & & & & & & \\
\hline & Cement & $5(1)$ & 189 & - & - & 0.75 & - & - & 19 & - & - \\
\hline & Marble & $2(1)$ & 212 & - & - & 0.85 & - & & 21 & - & - \\
\hline & Slate & $2(2)$ & 162 & 48 & $127-196$ & 0.65 & 0.19 & $0.51-0.78$ & 16 & 4.9 & $12.9-20$ \\
\hline \multirow[t]{5}{*}{ NM } & Granite & $9(9)$ & 802 & 905 & $224-2843$ & 3.2 & 3.6 & $0.9-11$ & 81 & 91 & $23-287$ \\
\hline & Ceramic & $7(1)$ & 9.2 & - & - & 0.04 & - & - & 0.9 & - & - \\
\hline & Wood & $1(0)$ & - & - & - & - & - & - & - & - & - \\
\hline & Aggregate & $2(1)$ & 1985 & - & - & 7.9 & - & - & 200 & - & - \\
\hline & Zircon & $2(2)$ & 3206 & 75 & $219-6193$ & 13 & 17 & $0.9-25$ & 323 & 426 & $22-624$ \\
\hline PM & Gypsum & $2(1)$ & 146 & - & - & 0.58 & - & - & 15 & - & - \\
\hline
\end{tabular}

2 


\section{Table 4 (on next page)}

${ }^{220} \mathrm{Rn}$ surface exhalation rate, $E_{\mathrm{A}}$, activity concentration in the air of the room at $40 \mathrm{~cm}$ from the wall, $A_{\mathrm{Rn} 220}$, and annual effective dose, $D_{\mathrm{Rn} 220}$, for the different building materials. 


\begin{tabular}{|c|c|c|c|c|c|c|c|c|c|c|c|}
\hline \multirow{2}{*}{\multicolumn{2}{|c|}{ Building materials }} & \multirow{3}{*}{$\begin{array}{c}\begin{array}{c}\mathbf{N}^{0} \text { of } \\
\text { samples }\end{array} \\
9\end{array}$} & \multicolumn{3}{|c|}{ 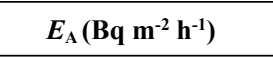 } & \multicolumn{3}{|c|}{$A_{\mathrm{Rn} 220}\left(\mathrm{~Bq} \mathrm{~m}^{-3}\right)$} & \multicolumn{3}{|c|}{$D_{\mathrm{Rn} 220}\left(\mu \mathrm{Sv} \mathrm{y}^{-1}\right)$} \\
\hline & & & \multirow{2}{*}{$\begin{array}{c}\text { Mean } \\
44\end{array}$} & \multirow{2}{*}{$\begin{array}{l}\text { SD } \\
18\end{array}$} & \multirow{2}{*}{$\begin{array}{l}\text { Range } \\
26-82\end{array}$} & \multirow{2}{*}{$\begin{array}{c}\text { Mean } \\
3.9\end{array}$} & \multirow{2}{*}{$\begin{array}{l}\text { SD } \\
1.6\end{array}$} & \multirow{2}{*}{$\begin{array}{l}\text { Range } \\
2.3-7.2\end{array}$} & \multirow{2}{*}{$\frac{\text { Mean }}{55}$} & \multirow{2}{*}{$\begin{array}{l}\text { SD } \\
39\end{array}$} & \multirow{2}{*}{$\begin{array}{c}\text { Range } \\
27-147\end{array}$} \\
\hline & Concrete & & & & & & & & & & \\
\hline & Cement & 5 & 22 & 6.0 & $18-32$ & 2.0 & 0.5 & $1.6-2.9$ & 24 & 5.8 & $19-33$ \\
\hline & Marble & 2 & 27 & 4.6 & $24-31$ & 2.4 & 0.4 & $2.1-2.7$ & 28 & 4.8 & $25-32$ \\
\hline & Slate & 2 & 214 & 32 & $191-236$ & 19 & 2.8 & $17-21$ & 220 & 32.8 & $197-243$ \\
\hline \multirow[t]{5}{*}{ NM } & Granite & 9 & 315 & 478 & $27-1530$ & 28 & 42 & $2.4-135$ & 325 & 493 & $28-1580$ \\
\hline & Ceramic & 7 & 24 & 13 & $17-53$ & 2.1 & 1.1 & $1.5-4.7$ & 25 & 13 & $18-55$ \\
\hline & Wood & 1 & 959 & - & - & 85 & - & - & 989 & - & - \\
\hline & Aggregate & 2 & 47 & 109 & $15-80$ & 4.2 & 4.1 & $1.3-7.1$ & 49 & 48 & $15-83$ \\
\hline & Zircon & 2 & 1264 & 12 & $42-2485$ & 112 & 153 & $3.7-220$ & 1300 & 1780 & $43-2560$ \\
\hline PM & Gypsum & 2 & 18 & 5.9 & $14-22$ & 1.4 & 0.3 & $1.2-1.6$ & 16 & 3.1 & $14-19$ \\
\hline
\end{tabular}

